\title{
Multidisciplinary Investigations of Alpine Ice Patches in Southwest Yukon, Canada: Paleoenvironmental and Paleobiological Investigations
}

\author{
RICHARD FARNELL, ${ }^{1}$ P. GREGORY HARE,${ }^{2}$ ERIK BLAKE, ${ }^{3}$ VANDY BOWYER,${ }^{4}$ CHARLES SCHWEGER, ${ }^{4}$ \\ SHEILA GREER ${ }^{5}$ and RUTH GOTTHARDT ${ }^{2}$
}

(Received 25 November 2003; accepted in revised form 27 January 2004)

\begin{abstract}
Since the discovery of dung-rich alpine ice patches in southwest Yukon in 1997, continuing multidisciplinary studies have provided a unique window on the biology, climate, and hunting activity in this region over much of the Holocene. Aerial surveys have identified 72 ice patches of variable size, and 65 patches have been ground-surveyed for organic remains. Of these, 35 yielded an abundance of biological specimens, including caribou and other rare large mammal remains, mummified small mammals and birds, and artifacts spanning 8000 years. The dung provides pollen and plant macrofossils for analysis and paleoenvironmental reconstruction, as well as dietary, genetic, and parasitic information. Stratigraphically controlled sampling of dung within ice layers has yielded a geochronology placing their formation as early as 8300 to 8000 years BP. Ice patch formation was nearly continuous except for an interval between 6700 and 4700 years BP and another between 1440 and 1030, when warm or dry conditions (or both) resulted in no net ice accumulation. Resumption of ice accumulation over the following 500 years likely culminated in the Little Ice Age. The size of the ice patches during this period is made evident by a lichen-free zone that haloes each patch. More recently, interpretation of air photos from 1946 to 2001 has found a significant reduction in ice patch dimensions. Daily temperature records for Whitehorse (1942-2001) were used to calculate melting degree-day values that account for a large part of the variation in ice patch size, indicating that while considerable melting has likely occurred since the end of the Little Ice Age, the ice patches are highly sensitive to decadal changes in temperature.
\end{abstract}

Key words: Rangifer tarandus, permanent snowfields, climate change, Holocene mammals, Little Ice Age, paleoenvironment, caribou diet, pollen, genetics, parasites

RÉSUMÉ. Depuis la découverte de plaques de glace alpines riches en excréments d'animaux dans le sud-ouest du Yukon en 1997, des études multidisciplinaires continues offrent une fenêtre unique sur la biologie, le climat et les activités de chasse de la région pendant presque toute la période de l'Holocène. À l'aide de relevés aériens, il a été possible d'identifier 72 plaques de glace de tailles différentes. Des relevés sur le terrain ont été effectués sur 65 de ces plaques pour récupérer des restes organiques, et 18 d'entre-elles ont révélé une abondance d'espèces biologiques et des restes de grands mammifères rares (y compris le caribou), des petits mammifères et des oiseaux momifiés, et des artéfacts datant jusqu'à 8000 ans. Les excréments d'animaux permettent d'analyser des macrofossiles de pollen et de plantes afin de faire une reconstruction paléoécologique, ainsi que d'obtenir des renseignements sur le régime alimentaire, la génétique et les parasites. À l'aide de la géochronologie, l'échantillonnage des excréments d'animaux contrôlé par stratigraphie a permis de dater la formation des excréments à aussi loin que 8300 à 8000 ans B.P. La formation des plaques de glace a été presque continue, à l'exception d'une période entre 6700 et 4700 ans B.P. et d'une autre entre 1440 et 1030, lorsque des conditions chaudes ou sèches ou les deux n'ont pas permis à la glace de s'accumuler. La reprise de l'accumulation de glace au cours des 500 dernières années a vraisemblablement provoqué le petit âge glaciaire. La taille des plaques de glace au cours de cette période est facilement calculable grâce aux zones sans lichen qui encerclent chaque plaque. Des études plus récentes de photos aériennes prises entre 1946 et 2001 ont permis de constater une réduction marquée de la taille des plaques de glace. Les données des températures quotidiennes de Whitehorse (de 1942 à 2001) ont été utilisées pour calculer la valeur du degré-jour de fonte qui est en grande partie responsable de la variation de la taille des plaques de glace. Ces données indiquent que même si le plus gros de la fonte s'est produit depuis la fin du petit âge glaciaire, les plaques de glace réagissent beaucoup aux changements de température décennaux.

Mot clés: Rangifer tarandus, champs de neige permanents, changement climatique, mammifères de l'Holocène, petit âge glaciaire, paléoécologie, régime alimentaire du caribou, pollen, génétique, parasites

Translated by Jean-François Roldan, Bureau of French Language Services, Government of Yukon.

\footnotetext{
${ }^{1}$ Department of Environment, Government of Yukon, Box 2703, Whitehorse, Yukon, Y1A 2C6, Canada; Rick.Farnell@ gov.yk.ca

${ }^{2}$ Department of Tourism and Culture, Government of Yukon, Box 2703, Whitehorse, Yukon, Y1A 2C6, Canada

${ }^{3}$ Icefield Instruments Inc., Box 30036, Whitehorse, Yukon Y1A 5M2, Canada

${ }^{4}$ Department of Anthropology, University of Alberta, Edmonton, Alberta T6G 2H4, Canada

${ }^{5}$ Champagne and Aishihik First Nations; Canadian Circumpolar Institute, University of Alberta; address: 8441 - 118th Street, Edmonton, Alberta T6G 1T2, Canada

(c) The Arctic Institute of North America
} 


\section{INTRODUCTION}

During the warm summer of 1997, extensive deposits of prehistoric caribou (Rangifer tarandus sp.) dung and a small fragment of a 4000-year-old hunting dart were collected from a melting alpine ice patch in southern Yukon Territory (Kuzyk et al., 1999). Since then, dozens of Yukon ice patches containing organic remains dating to more than 8000 years BP have been identified. An exceptional collection of perishable hunting artifacts, mummified small mammals and birds, large mammal bones, antler and horn, feces of herbivore species, and an abundance of paleoenvironmental proxy evidence have been recovered. The abundance of dung associated with the ice patches was unexpected, as only two herds of woodland caribou, the Aishihik herd of 1500 animals and the Ibex herd of 450, occupy the study area at present. A large body of First Nations oral history indicates, however, that caribou were far more abundant and widespread as recently as the $1930 \mathrm{~s}$ (Anne Ned in Cruikshank et al., 1990; elder Jimmy G. Smith in Champagne and Aishihik First Nations Oral History Files, n.d.). Caribou are known to seek out ice patches during hot weather in summer (June to August) both for thermal regulation and to escape biting insects. Similar behavior in the past may account for the concentrations of dung pellets in the ice patches and the attraction that ice patches held for prehistoric hunters.

The ice patch record of extraordinary, well-preserved perishable materials provides a unique window on the biology, climate, and hunting activity in the southern Yukon over much of the Holocene. With this insight, the multidisciplinary Ice Patch Research Project was formed to advance discoveries and research ice patch sites and the materials they contain. This paper provides an overview of the project research; presents preliminary results of radiocarbon geochronology, ice patch formation, paleoenvironmental reconstructions, and vertebrate biology; and discusses future research and its implications. The ethnography and archaeology of the southern Yukon ice patches are presented in the following article (see Hare et al., 2004, this volume).

\section{ENVIRONMENTAL SETTING}

Southern Yukon occurrences of alpine ice include both glaciers and ice patches. They differ in that glaciers achieve sufficient mass to cause ice to flow, while ice patches apparently do not acquire enough mass for flow (Glen, 1955; Paterson, 1981) and therefore may exhibit bands of caribou dung along exposed ice faces (Fig. 1). The majority of ice patches described here are located in the Haines Junction-Whitehorse-Carcross area of southern Yukon, within the northerly portion of the Coast Range and adjacent Yukon Plateau. The area of ca. $18350 \mathrm{~km}^{2}$ lies mainly within the Yukon Southern Lakes, Ruby Ranges, and Yukon-Stikine Highlands ecoregions (Smith et al., 2003)

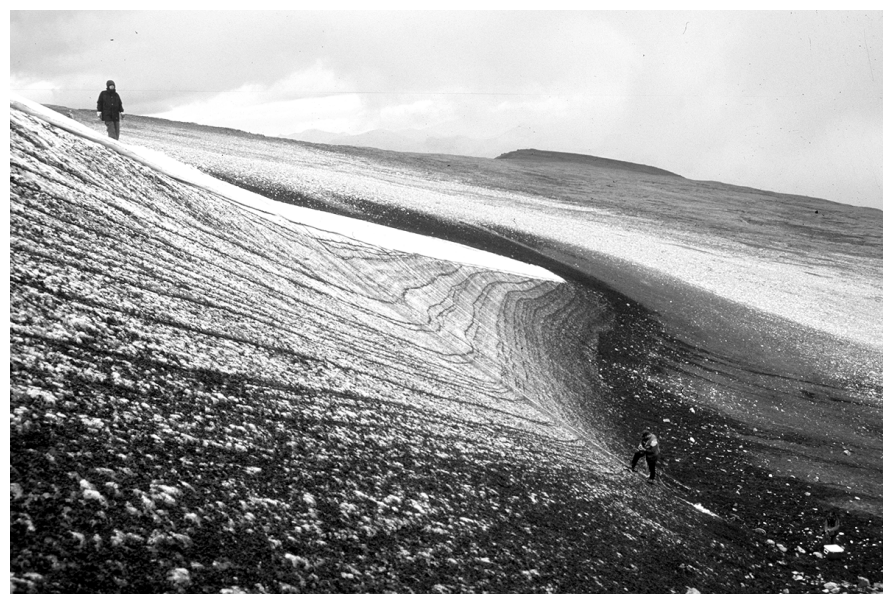

FIG. 1. The Granger ice patch, showing layers of caribou dung in the exposed ice face.

(Fig. 2). Mean low elevation temperatures for this region are similar, with mean annual temperature ca. $-3^{\circ} \mathrm{C}$, mean summer temperature ca. $10^{\circ} \mathrm{C}$, and mean winter temperature ca. $-17^{\circ} \mathrm{C}$. Common winter inversions lead to milder temperatures at higher elevation. This semiarid region receives 250-300 $\mathrm{mm}$ mean annual precipitation (Wahl et al., 1987). The lack of moisture limits growth of glaciers at higher elevations, and it is evident in the open forest vegetation of the U-shaped and commonly lake-filled valley bottoms. Lower slopes and valley bottoms are forested by white (Picea glauca) and black (Picea mariana) spruce with alder (Alnus crispa), willows (Salix spp.), birches (Betula papyrifera and B. glandulosa), and ericaceous shrubs. Black spruce, willow, birch, and mosses (Sphagnum spp.) are common to poorly drained sites. Alpine fir (Abies lasiocarpa) occurs in the subalpine region, often forming the tree line at $1050-1200 \mathrm{~m}$ asl. Alpine communities include mountain avens (Dryas spp.), dwarf willow, shrub birch, ericaceous shrubs, graminoid species, and mosses (Smith et al., 2003). Large mammals are moose (Alces alces), caribou, and Dall sheep (Ovis dalli); principal predators are wolf (Canis lupus), bears, both brown (Ursus arctos) and black (U. americanus), lynx (Lynx canadensis), coyote (Canis latrans), and wolverine (Gulo gulo). In the last century, about 200 wapiti (Cervus elaphus) and 400-500 wood bison (Bison bison athabascae) were introduced into the Aishihik area (R. Farnell, unpubl. data).

\section{ICE PATCH INVENTORY}

\section{Present Distribution}

Aerial surveys were flown within the Coast Range and Yukon Plateau from 1998 to 2003, during the period of maximum melt (from late July to mid August). These surveys identified 72 dung-rich ice patches between 1550 and $2075 \mathrm{~m}$ asl, but not necessarily on the highest peaks 


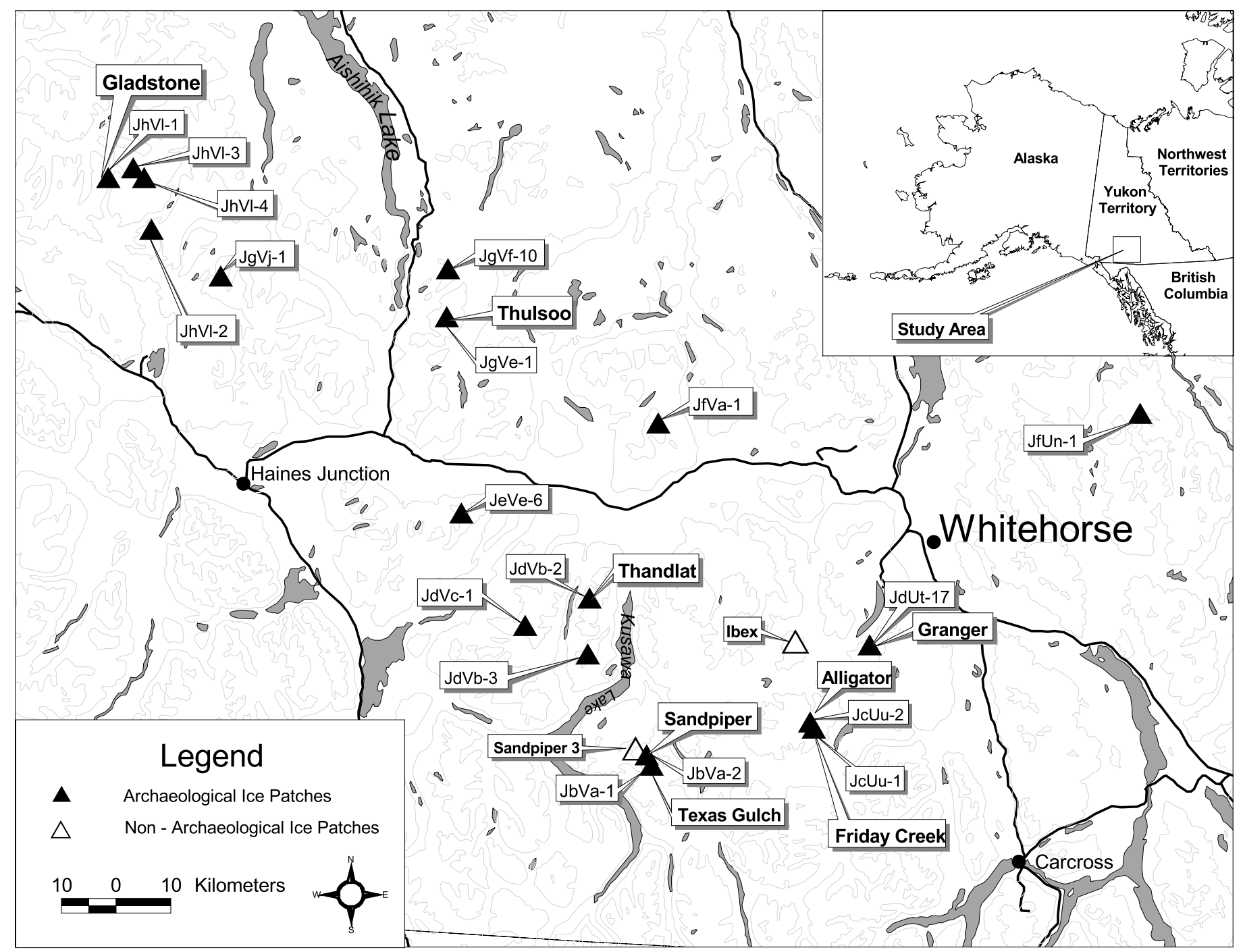

FIG. 2. Map of study area, showing distribution of ice patches, sites bearing artifacts, and the three reference sites.

(up to $2709 \mathrm{~m}$ ). The ice patches are confined to northwest-, north-, or northeast-facing slopes, often within cirques or nivation hollows (Washburn, 1979), and they range from less than $100 \mathrm{~m}$ to almost a kilometer in length and from about $10 \mathrm{~m}$ to more than $80 \mathrm{~m}$ in height. The caribou dung varies in preservation from firm, well-formed pellets to a dark, amorphous organic soil located at the edges of some ice patches. It appears that at a number of patches, dung is still preserved in the ice in situ, while at other patches, the dung had melted out previously to form a basal soil of partially decomposed feces. Ice-free sites at lower elevations may have been ice patch locations in the past, and dung-rich ice patches may also exist at higher elevations, where insufficient melting limits observation. It is not known whether such ice patch phenomena occur elsewhere in southern Yukon, but it is likely they also occur outside our study area. (Fig. 2).

Caribou appear to congregate on ice patches to avoid insect harassment and for thermal regulation (Downes et al., 1986; Ion and Kershaw, 1989; Anderson and Nilssen,
1998). Some patches may, of course, be too small or steep to provide suitable relief, and ice patches at higher elevation may be preferred as there are fewer biting insects. Casual ice patch use is not likely to be a factor that determines summer herd movements, such as dispersal at calving, predator avoidance, and forage selection. Longterm use of a particular ice patch is indicative of its persistence on the landscape and central location relative to the summer habitation for a population. Isolated ice patches could be a limiting factor on some summer ranges; for example, the Klaza herd of west-central Yukon is observed to congregate around a single large ice patch in its range. Use of certain "traditional" ice patches could be learned behavior, similar to caribou use of specific mineral licks.

Sixty-five patches have been examined on the ground, and their ice surfaces and the un-vegetated areas around the ice patches surveyed for organic remains. While biological specimens have been found at approximately 35 patches and archaeological artifacts at 18 patches, there 
TABLE 1. Properties of reference ice patches.

\begin{tabular}{lccc}
\hline \hline & Thandlät & Granger & Friday Creek \\
\hline Map Coordinates & $60^{\circ} 35^{\prime} 50^{\prime \prime} \mathrm{N}$ & $60^{\circ} 32^{\prime} 28^{\prime \prime} \mathrm{N}$ & $60^{\circ} 23^{\prime} 26 " \mathrm{~N}$ \\
& $136^{\circ} 15^{\prime} 18^{\prime \prime} \mathrm{W}$ & $135^{\circ} 15^{\prime} 25^{\prime \prime} \mathrm{W}$ & $135^{\circ} 26^{\prime} 30^{\prime \prime} \mathrm{W}$ \\
Elevation (m) & 1829 & 1890 & 1960 \\
Aspect & $360^{\circ}$ & $40^{\circ}$ & $50^{\circ}$ \\
Length (m) & 950 & 650 & 720 \\
Height $(\mathrm{m})$ & 28.2 & 14.2 & 88 \\
Ice Surface Slope & $33.0^{\circ}$ & $37.6^{\circ}$ & $24.7^{\circ}$ \\
Exposed Surface $(\mathrm{m})$ & $(\mathrm{SD}=4.32)$ & $(\mathrm{SD}=1.14)$ & $(\mathrm{SD}=0.82)$ \\
& 28.2 & 14.2 & 88.0 \\
\hline \hline
\end{tabular}

appears to be a strong correlation between the abundance of artifacts and recovered faunal remains. The most productive ice patches (named with reference to nearby geographical features) are Thandlät, Thulsoo, Gladstone, Granger, Friday Creek, Alligator, Sandpiper, and Texas Gulch (Fig. 2). All but ten prehistoric artifacts were recovered from these eight sites. Three sites, the Thandlät, Granger, and Friday Creek ice patches, were selected as reference sites because of their large size and numerous dung-rich layers, and these sites received more detailed description and sampling (Table 1). At each of these sites, the dung was preserved in situ.

\section{Field and Laboratory Methods}

Ice surface slope angles were measured using a surveyor's clinometer. Vertical measurements of stratigraphy and sample location were made along the exposed, sloping face of the ice patches. Blocks of clean and dung-rich ice were cut from the ice face with a lubricant-free chain saw and kept frozen until eventual laboratory analysis. All biological specimens were stored at $-15^{\circ} \mathrm{C}$ within hours of collection and kept at this temperature until distribution to specialists. Large mammal material was submitted to D. Balkwill and S. Cumbaa, Canadian Museum of Nature, for species identification, and 17 caribou mandibles were sent to the Contaminants Unit, Department of Indian and Northern Affairs (Canada), for measurement of pre-industrial heavy metal contamination levels. Small mammal and bird material was provided to the University of Alaska $\mathrm{Mu}-$ seum Frozen Tissue Collection.

AMS ${ }^{14} \mathrm{C}$ dates were determined by University of Toronto Isotrace Laboratory; Beta Analytic Inc., Miami, Florida; and Lawrence Livermore National Laboratory, University of Southern California. All results are expressed as uncalibrated radiocarbon dates. Pollen and plant macrofossil analysis was performed by V. Bowyer, University of Alberta Laboratory for Paleoenvironmental Studies. Preparation of organic-rich samples followed standard methods (Moore et al., 1991); ice samples followed Bourgeois (2000). Fecal samples from Friday Creek were particularly easy to collect in volume, and sub-samples were submitted to three laboratories. B. Davitt, Washington State University Wildlife Habitat and Nutrition Laboratory, performed microhistological diet analysis.
E. Shapiro, Oxford University Ancient Biomolecules Centre, extracted nuclear and mitochondrial DNA. DNA study methods followed manufacturer's instructions for the QiaGen DNeasy Stool Kit (QiaGen), and to confirm authenticity of the extracted DNA, 250-300 base pairs were amplified and sequenced as in Barnes et al. (2002). P. Wallis, Hyperion Research Ltd., Medicine Hat, Alberta, undertook parasite research.

\section{ICE PATCH FORMATION AND PALEOENVIRONMENTAL RECONSTRUCTION}

\section{Ice Patch Formation}

The black-and-white layering, exposed during the summer melt and clearly visible from a distance, is the most distinguishing feature of the ice patches. The discrete and near-parallel layers of concentrated organic materialmostly caribou dung, but also windblown detritus and rare animal remains and artifacts-are exposed across the face of the melting ice slope. These layers, separated by clean ice, incline $5^{\circ}-15^{\circ}$ downslope, intersecting the sloping ice surface $\left(25-40^{\circ}\right)$ at a shallow angle. The difference in slope between the dung layers and the ice surface may reflect gentler slopes during formation of the ice patch versus steeper slopes during periods of melting (as at present). Net accumulation of winter snow followed by compaction and regelation of summer melt formed the ice patches. Broadly, only about 100 layers are observed at any one site, and they are known to pinch out or merge. This, along with ${ }^{14} \mathrm{C}$ dates (discussed below), indicates that the layers of dung and detritus are not annual, but concentrations of organic material deposited on the ice patch surface over decades or centuries and then concentrated during melt periods into "super layers."

The lack of distortion in even the oldest layers and in the shape of the dung pellets, as well as broad agreement between stratigraphic levels and ${ }^{14} \mathrm{C}$ dates, indicates that little internal movement or associated shear has taken place in the ice patches over time. The maximum overall thickness of the ice patches is estimated to be $30-50 \mathrm{~m}$, which is marginal for flow (Glen, 1955). The presence of undisturbed vegetation beneath the Granger ice patch indicates that the base has not moved. Unfortunately, the relatively warm ice temperatures suggest re-crystallization of the ice and destruction of any ice crystal deformation needed to demonstrate flow.

\section{Geochronology and Paleoclimate}

Ice patch geochronology is provided by 42 AMS dates on stratigraphically controlled dung pellets and buried vegetation (Table 2). Paired dates on separate dung pellets from the same depth indicate the composite nature of the layers. Even though the majority of dates are in chronological sequence, one cannot rule out deposition and 
TABLE 2. Uncalibrated AMS dates on material recovered in stratigraphic layers in the Granger, Thandlät, and Friday Creek ice patch sites. Stratigraphic distances are measured from the base of each ice patch to the top. Discordant dates were resubmitted for a second analysis when fecal material sufficed.

\begin{tabular}{|c|c|c|c|c|c|}
\hline Reference Site & $\begin{array}{l}\text { Location } \\
\text { (m from the base) }\end{array}$ & $\begin{array}{l}\text { First Conventional } \\
{ }^{14} \mathrm{C} \text { Date }\end{array}$ & Lab No. & $\begin{array}{l}\text { Second Conventional } \\
{ }^{14} \mathrm{C} \text { Date }\end{array}$ & Lab No. \\
\hline Thandlät & $\begin{array}{c}28.2 \\
21.7 \\
14.6 \\
11.6 \\
7.2 \\
3.1 \\
0\end{array}$ & $\begin{array}{r}1850 \pm 50 \\
960 \pm 50 \\
1440 \pm 50 \\
1670 \pm 50 \\
1620 \pm 50 \\
2890 \pm 50 \\
7440 \pm 60\end{array}$ & $\begin{array}{l}\text { TO-7562 } \\
\text { TO-7560 } \\
\text { TO-7559 } \\
\text { TO-7558 } \\
\text { TO-7557 } \\
\text { TO-7556 } \\
\text { TO-7555 }\end{array}$ & & \\
\hline Mount Granger & $\begin{array}{c}14.2 \\
11.3 \\
10.3 \\
8.6 \\
7.4 \\
6.4 \\
5.3 \\
4.6 \\
3.7 \\
3.3 \\
2.9 \\
2.6 \\
2.3 \\
1.5 \\
0.7 \\
0 \\
\text { Vegetation }\end{array}$ & $\begin{array}{l}970 \pm 50 \\
1030 \pm 50 \\
1600 \pm 50 \\
1920 \pm 50 \\
1620 \pm 40 \\
1770 \pm 60 \\
1910 \pm 60 \\
2240 \pm 40 \\
3850 \pm 50 \\
\text { Modern } \\
3030 \pm 50 \\
4780 \pm 80 \\
7500 \pm 60 \\
8330 \pm 60 \\
7890 \pm 80 \\
6730 \pm 70 \\
7990 \pm 70\end{array}$ & $\begin{array}{l}\text { TO-7563 } \\
\text { TO-7564 } \\
\text { TO-7565 } \\
\text { TO-7566 } \\
\text { Beta-140621 } \\
\text { TO-7567 } \\
\text { TO-7568 } \\
\text { Beta-140622 } \\
\text { Beta-136360 } \\
\text { Beta-136359 } \\
\text { TO-7569 } \\
\text { Beta-136358 } \\
\text { Beta-136357 } \\
\text { Beta-136356 } \\
\text { Beta-136355 } \\
\text { TO-7570 } \\
\text { Beta-136354 }\end{array}$ & $\begin{array}{l}1460 \pm 40 \\
1650 \pm 40 \\
1980 \pm 40 \\
4180 \pm 40 \\
2380 \pm 40\end{array}$ & $\begin{array}{l}\text { Beta-162356 } \\
\text { Beta-140619 } \\
\text { Beta-140620 } \\
\text { Beta-140624 } \\
\text { Beta-162355 } \\
\text { Beta-140623 } \\
\text { Beta-162357 }\end{array}$ \\
\hline Friday Creek & $\begin{array}{r}88^{2} \\
77^{1} \\
67^{1} \\
54^{2} \\
40^{1} \\
36^{1} \\
33^{1} \\
3^{2} \\
0^{1}\end{array}$ & $\begin{array}{r}460 \pm 60 \\
1650 \pm 60 \\
1660 \pm 50 \\
2850 \pm 50 \\
3550 \pm 70 \\
3830 \pm 40 \\
4520 \pm 50 \\
4410 \pm 50 \\
4200 \pm 80\end{array}$ & $\begin{array}{l}\text { Beta-136346 } \\
\text { Beta-136347 } \\
\text { Beta-136348 } \\
\text { Beta-136349 } \\
\text { Beta-136350 } \\
\text { Beta-152447 } \\
\text { Beta-136351 } \\
\text { Beta-136352 } \\
\text { Beta-136353 }\end{array}$ & $\begin{array}{l}4310 \pm 40 \\
4440 \pm 40 \\
4190 \pm 40\end{array}$ & $\begin{array}{l}\text { Beta- } 152448 \\
\text { Beta- } 152449 \\
\text { Beta- } 152450\end{array}$ \\
\hline
\end{tabular}

${ }^{1}$ Samples used for caribou dietary analysis.

${ }^{2}$ Samples used for parasite studies.

regelation of contaminating organic matter transported by present day meltwater along cracks or the organic layers.

Despite the relatively coherent chronological stratigraphy demonstrated at the ice patches, temporal gaps are evident. Dates on dung from the base of the Granger ice patch and vegetation beneath the ice patch place its formation at 8300 to 8000 years BP (Table 2). Dated dung at the base of the Thandlät and Friday Creek ice patches places their formation at ca. 7400 years BP and 4500 years BP, respectively. Ice patch formation was nearly continuous except for the interval between 6730 and 4780 years BP (Fig. 3). The base of Thandlät dates at $7440 \pm 60$ years BP, while the next date, $3.1 \mathrm{~m}$ above, is $2890 \pm 50$ years BP. The temporal gap at Granger, from 2.3 to $2.6 \mathrm{~m}$, is between $7500 \pm 60$ and $4780 \pm 80$ years BP. Significantly, the basal date at Friday Creek indicates accumulation of ice after $4520 \pm 50$ years BP. These dates suggest that no net ice accumulation occurred over a midHolocene interval of 1950 years, or that accumulated ice was condensed during a period of intensive melting. However the lack of evidence for oversteepening of the paleoice surface does not support ice reduction.
The alpine ice patches reflect the sensitive balance between accumulation and ablation, and while midHolocene ice may yet be dated, the ice patch record provides a paleoclimatic record for southern Yukon. Accumulation of ice at Granger and Thandlät occurred following a warmer or drier ice-free interval during the late glacial, early Holocene (Denton and Karlén, 1973). From 6700 to 4700 years BP, increased temperature or reduced precipitation, or both, resulted in no net ice accumulation. This period was followed by nearly 5000 years of reduced temperatures or increased precipitation, or both, resulting in significant ice accumulation at all three sites. Accumulation over the last 2000 years is especially noticeable and may broadly correlate to the Neoglaciation (Denton and Stuiver, 1967). The interval from 1440 to 1030 BP (AD 510 to 920 ), when we speculate that ice did not accumulate, falls within the Medieval Warm Period (Hughes and Diaz, 1994). Resumption of ice accumulation over the past 1000 years likely culminated in the Little Ice Age (LIA). The size of the ice patches during the LIA is assumed to be shown by the bare, light-coloured rock that forms a halo around the dark, lichen-covered (Umbilicaria sp.) rock of 


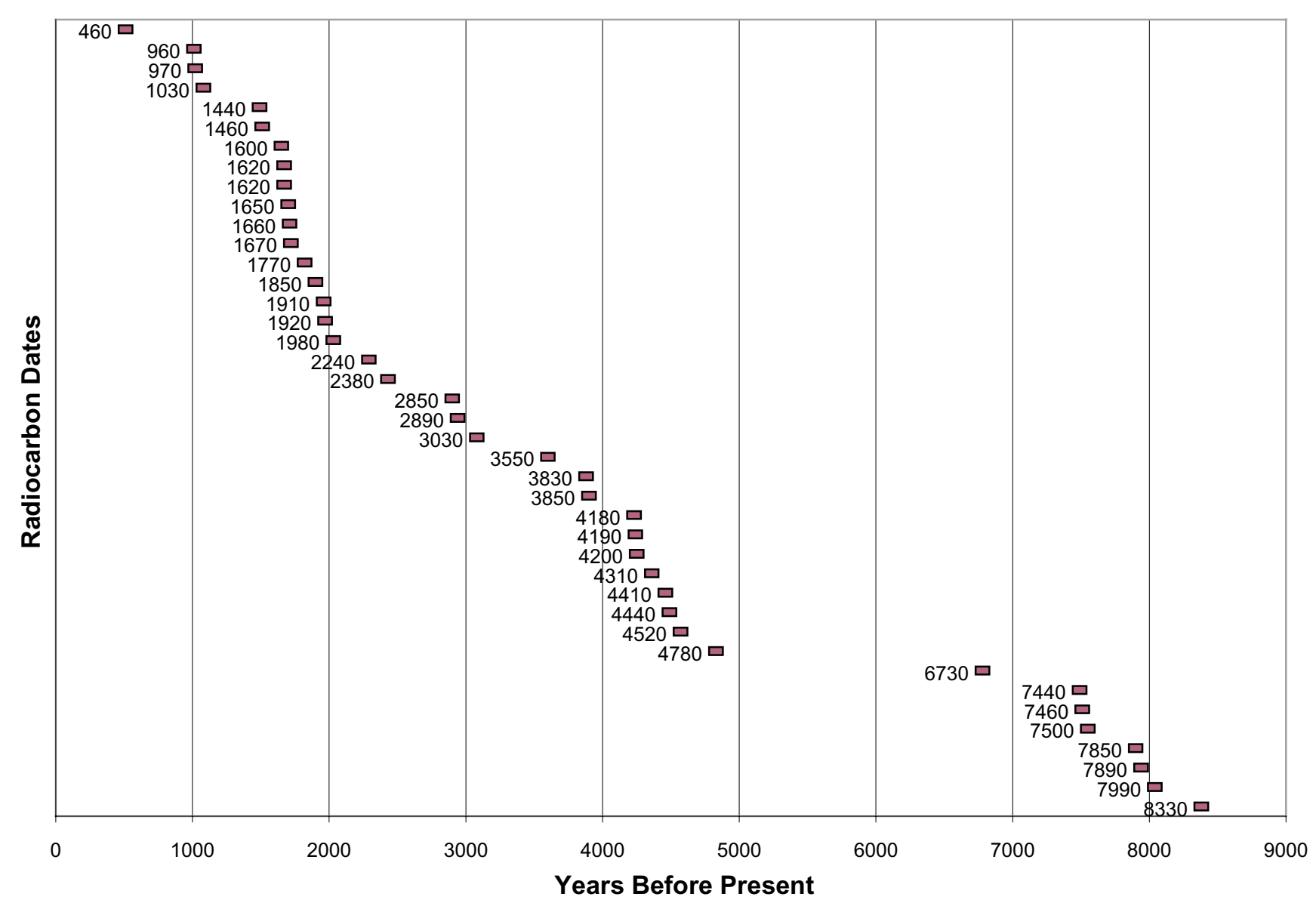

FIG. 3. Plot of uncalibrated AMS dates on organic layers in the three reference ice patches.

each ice patch (Fig. 4). This lichen-free zone (LFZ) marks the extent of perennial snow and ice cover that prevented lichen growth and is a proxy for the larger size of ice patches at the end of the LIA.

This record is somewhat at variance with other paleoclimate sequences for southern Yukon that suggest a warm and wet "thermal maximum" from 8000 to 2500 years BP (Miller and Anderson, 1974) and cooler and moister conditions at about 6000 years BP (Cwynar and Spear, 1995).

The three reference ice patch sites have similar northward aspects that range from $360^{\circ}$ to $50^{\circ}$ and elevations that range from 1829 to $1960 \mathrm{~m}$ asl, while the slopes and therefore the size of their exposed ice faces differ (Table 1). Consequently, Friday Creek has the greatest exposure to solar radiation, which makes it the most vulnerable to total ablation during warm climatic periods.

\section{Recent Climate Change}

Vertical air photos of the reference sites (including the Alligator ice patch, adjacent to Friday Creek) from 1946 to 1995 were obtained from the National Air Photo Library and used to determine reduction of ice patch size and the rate of melt. Dimensions of the LFZ and ice patch size in 2001 were quantified on the ground using differential GPS mapping (Global Tremble 3 Pathfinder Office). Persistent snow cover and photographic overexposure of snow and ice limited precise determination of ice patch perimeters and therefore their areal extents. Significant reduction in ice patches has occurred since 1946 (Table 3). Granger had almost disappeared by 1995 , having been reduced to less than a hectare, or only $6 \%$ of its LFZ. Thandlät, Alligator, and Friday Creek were reduced to $19 \%, 14 \%$, and $11 \%$, respectively, of their LIA dimensions. Equilibrium or accumulation occurred ca. 1960 to 1980 and 2000 to 2001, when sizeable snow aprons formed around the ice patches.

The melting trend for ice patches in the past century appears to relate to general patterns in recorded temperature change. Daily temperature records for Whitehorse (1942 -2001) were used to calculate Melting Degree Days (MDD) for May to September (Fig. 5). These were adjusted to $1830 \mathrm{~m}$ asl, the elevation of most dung-bearing ice patches, using a $0.65^{\circ} \mathrm{C} / 100 \mathrm{~m}$ lapse rate (Eley and Findlay, 1977), as follows:

$\Sigma$ May-Sept. $\{\Sigma$ Min $\{($ Daily Max Temp + Daily Min Temp)/2 - Lapse rate correction, 0$\}\}$

The melting degree value for a given day is the number of degrees by which the average daily temperature exceeds freezing (or is equal to zero if the average temperature is below freezing). We estimated temperatures at the 


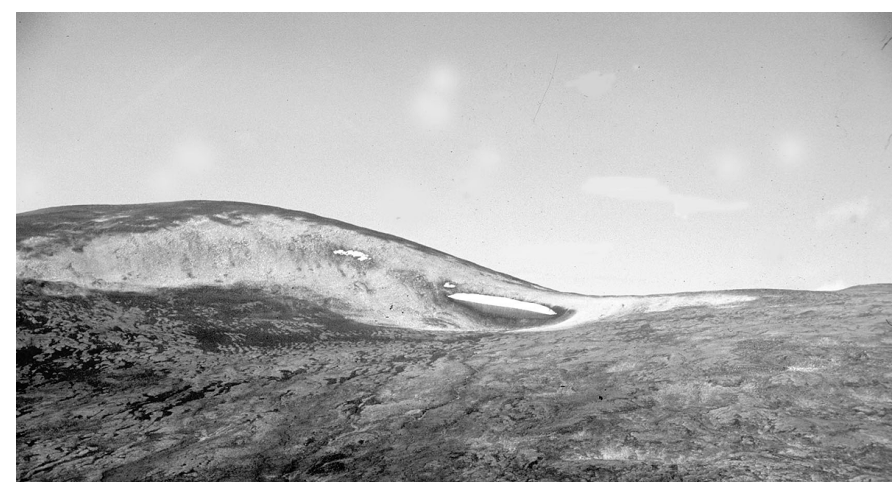

FIG. 4. Granger ice patch, clearly showing the associated lichen-free zone (LFZ).

TABLE 3. Estimates of areal extent of ice patches and LFZ between 1946 and 2001. Calculated as area of horizontal surface.

\begin{tabular}{|c|c|c|c|}
\hline SITE & Year & $\begin{array}{l}\text { Size } \\
\text { (ha) }\end{array}$ & $\begin{array}{c}\text { Size } \\
\text { (\% relative to LFZ) }\end{array}$ \\
\hline \multirow{5}{*}{ Thandlät } & LFZ & 40.19 & 100 \\
\hline & 1948 & 11.75 & 29 \\
\hline & 1972 & 10.02 & 25 \\
\hline & 1988 & 10.02 & 25 \\
\hline & 2001 & 7.54 & 19 \\
\hline \multirow[t]{5}{*}{ Granger } & LFZ & 13.26 & 100 \\
\hline & $1946^{1}$ & 2.95 & 22 \\
\hline & $1966^{2}$ & 8.50 & $64^{3}$ \\
\hline & 1995 & 0.83 & 6 \\
\hline & $2001^{4}$ & 4.28 & 32 \\
\hline \multirow[t]{6}{*}{ Alligator $^{5}$} & LFZ & 26.05 & 100 \\
\hline & 1946 & 6.05 & 23 \\
\hline & 1966 & 9.90 & 38 \\
\hline & 1987 & 5.83 & 22 \\
\hline & 1995 & 3.62 & 14 \\
\hline & 2001 & 5.41 & 21 \\
\hline \multirow[t]{6}{*}{ Friday Creek } & LFZ & 25.09 & 100 \\
\hline & 1946 & $-{ }^{6}$ & \\
\hline & 1966 & 7.82 & 31 \\
\hline & 1987 & -7 & \\
\hline & 1995 & 2.83 & 11 \\
\hline & 2001 & 4.48 & 21 \\
\hline
\end{tabular}

${ }^{1}$ Two pieces.

${ }^{2}$ Once piece remaining.

${ }^{3}$ Since the ice patch appears to exceed the perimeter of the LFZ, we believe that there exists a wide, and perhaps temporary, snow apron.

${ }^{4} 2001$ data were collected with GPS. Both 2000 and 2001 were years of net accumulation.

${ }^{5}$ The Friday site consists of two adjacent patches, Alligator to the north and Friday Creek to the south.

${ }^{6}$ No coverage due to flight path.

${ }^{7}$ Too much snow.

approximate elevation of the ice patches $(1830 \mathrm{~m})$ by correcting temperatures measured at Whitehorse (elevation $625 \mathrm{~m}$ ), using a lapse correction of $0.65^{\circ} \mathrm{C}$ per $100 \mathrm{~m}$ of elevation. Thus, the lapse rate correction to $1830 \mathrm{~m}$ is calculated as $7.8^{\circ} \mathrm{C}=(1830 \mathrm{~m}-625 \mathrm{~m}) / 100 \mathrm{~m} \times 0.65$.
From 1942 to 2001, the adjusted average MDD was highest during the decades of the 1950s and 1990s (Fig. 5): $10.6 \%$ and $11.3 \%$, respectively, above the $1942-99$ average of 541 MDD per year. Cooler and less variable temperatures occurred from 1959 to 1989 . The decades of the $1960 \mathrm{~s}, 1970 \mathrm{~s}$, and $1980 \mathrm{~s}$ were $3.9 \%, 13.7 \%$, and $6.9 \%$, respectively, below the $1942-99$ averages, with minimum MDD values set in 1970 and 1973. The decade of the 1980s is closer to earlier decades if the exceptionally warm 1989 value is eliminated. These MDD variations are consistent with the changes in area and volume of the reference ice patches. Considerable melting likely occurred at the end of the LIA and continued through the 1950s, after which Granger and Alligator increased and Thandlät stabilized. Renewed melting began after 1988 at Thandlät and sometime after 1966 at Granger, Alligator, and Friday Creek. These three patches also recorded slight growth during the cool summers of 2000 and 2001. Adjusted MDD values account for a large part of the variation in ice patch size and indicate that the ice patch size is highly sensitive to decadal changes in temperature.

\section{Paleoenvironmental Reconstruction}

Preserved dung and ice samples provide a rich repository of micro- and macrobotanical remains that record different aspects of the past environment compared to lake sediment records. While the latter capture regional vegetation over a temporal scale of decades, centuries, or millennia, a single dung pellet, in contrast, may represent the diet of a single caribou spanning up to several days (cf. van der Knapp, 1989; Gajewski et al., 1995). However, the composite paleobotanical record from ice patches can test and complement previous interpretations of southwestern Yukon vegetation histories based on sediment cores from lakes and bogs (cf., Rampton, 1971; Cwynar, 1988; Stuart et al., 1989; Wang and Guerts, 1991a, b; Keenan and Cwynar, 1992; Cwynar and Spear, 1995; Lacourse and Gajewski, 2000).

Samples from the ice patches consist of well-preserved individual caribou dung pellets, bulk "dirty" ice samples with a mixture of organic debris, and "clean" ice (with no visible organics). Combinations of windblown pollen, plants consumed by caribou and defecated onto the ice, and pollen attached to those plants (possibly for a time of several months) may contribute to the vegetation record contained within the ice patches. It must also be assumed that fossil ice patch assemblages likely include material redeposited during periods of thaw, when younger material accumulated with older material to form one organic layer. Taphonomic factors that influence the composition of micro- and macrobotanical assemblages in caribou dung and ice samples must be identified, as they will influence the record and subsequent interpretations (cf. Moe, 1983; van der Knapp, 1989; Bourgeois, 1990, 2000; Rasmussen, 1993; Gajewski et al., 1995; Zutter, 1999). To address this issue, modern caribou dung from the study 


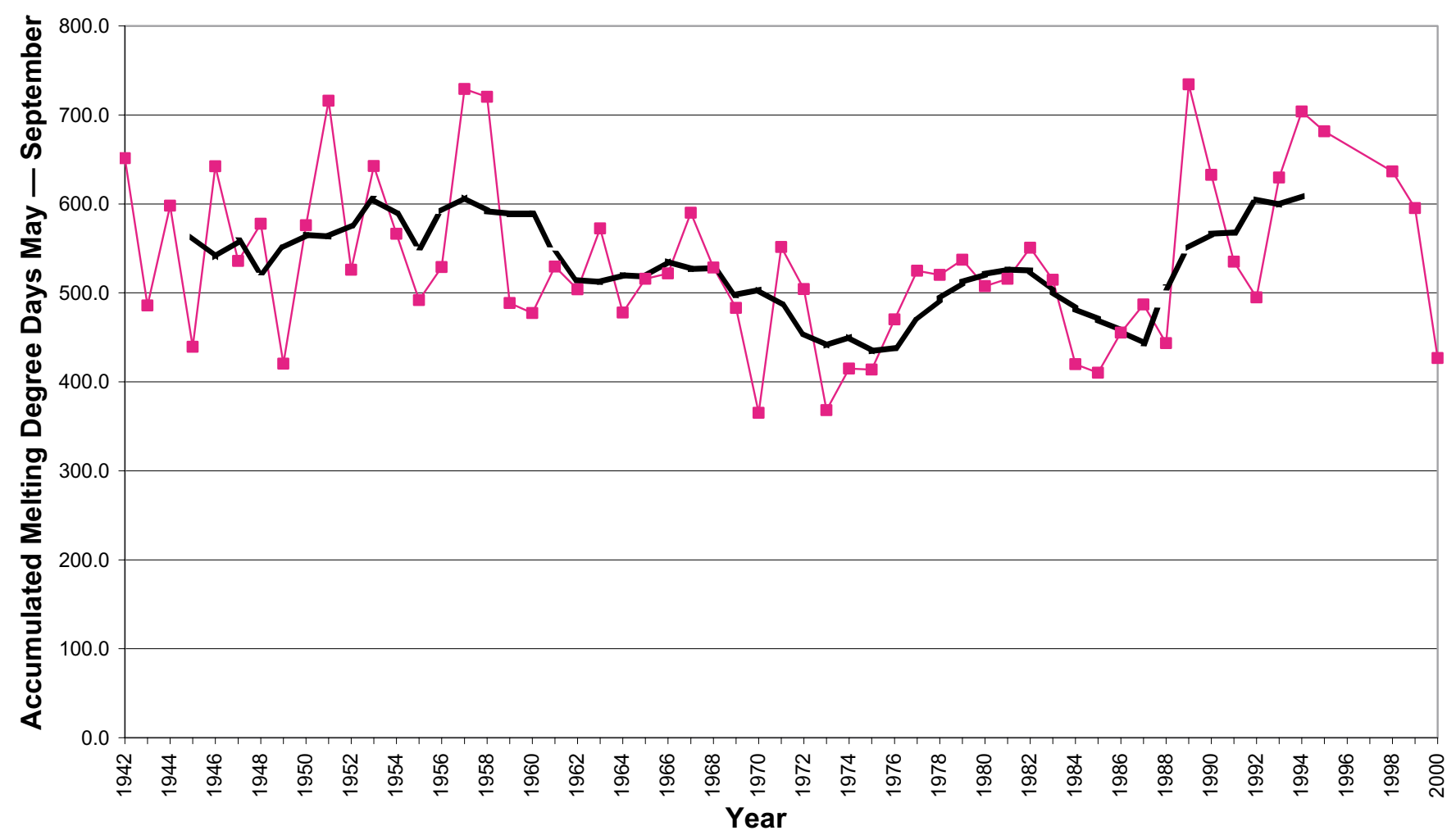

FIG. 5. Accumulated Melting Degree Days (MDD) corrected for lapse rate to $1830 \mathrm{~m}$. Heavy line illustrates five-year running average.

region has been collected to document seasonal differences (V. Bowyer, unpubl. data). These data make it possible to investigate environmental factors that influence pollen assemblages in caribou dung (cf. van der Knapp, 1989).

Preliminary analysis of pollen from the reference sites revealed evidence of spruce, pine, fir, alder, willow, birch, Cyperaceae (sedge), Artemisia (sage), Poaceae (grass), Ericaceae, Rosaceae, high and low spine Asteraceae, Equisetum (horsetail) and a variety of unknowns. Spruce, birch, willow, sedges, horsetail, and Artemisia are the most ubiquitous taxa found in fecal pellets and organicrich ice samples. Overall, there is greater diversity of taxa in dung and bulk organic-rich samples than in bulk "clean" ice samples, which are dominated by spruce and pine. Relatively high taxonomic diversity from ancient dung material may reflect spring or summer diet coincident with the pollination period, when caribou consume flowering plants and buds. In contrast, the limited diversity of pollen in ice samples might suggest early winter deposition, when pollen production is low (cf. Janzon, 1981; Haeberli et al., 1983; Bourgeois, 2000).

Paleoenvironmental records from Granger and Friday Creek ice patches exhibit an absence or very low occurrence of pine pollen until 1900 years ago, after which pine frequencies significantly increase (Bowyer and Schweger, 2001). Variable preservation suggests that some of the pollen may have been redeposited, possibly by water percolating through layers during summer melting. Nevertheless, these preliminary findings are in agreement with regional studies indicating that pine migrated into the region, reaching its northern range limits in south-central Yukon during the late Holocene (MacDonald and Cwynar, 1985, 1991; Cwynar, 1988). Additional sampling and analysis will refine the history of pine and further develop our understanding of the vegetation history of southwest Yukon.

\section{PRELIMINARY RESULTS OF BIOLOGICAL INVESTIGATIONS}

\section{Mammal Remains}

More than 100 mummified small mammal and bird remains have been recovered from southern Yukon ice patches. Preliminary identifications indicate that the majority are likely local alpine species, except for a duck and a muskrat (Ondatra zibethicus spatulatus). Nine AMS ${ }^{14} \mathrm{C}$ dates were determined on identified species common in the study area (Banfield, 1974). Three were modern (1950), while six were dated between 5320 and 500 years BP (Table 4).

Approximately 600 large mammal remains, including postcranial and cranial skeletal elements, antler, antler velvet, and horn sheaths, have been recovered from southwest Yukon ice patches. Caribou remains dominate, but isolated elements of wood bison, moose, sheep, wapiti, and goat (Oreamnos americanus) have also been identified to this point (D. Balkwill and S. Cumbaa, Canadian Museum of Nature, pers. comm. 2001). Ten identified specimens date from 7510 years BP to modern times (Table 4). 
TABLE 4. Species identification and uncalibrated radiometric data for selected small and large mammals.

\begin{tabular}{|c|c|c|c|c|}
\hline Lemтиs trimucronatus & Alligator & AF42781 & Beta- 154425 & $107.4 \pm 0.5 \mathrm{pMC}$ \\
\hline Microtus oeconoтиs & Marmot & AF42780 & Beta-154424 & $109.2 \pm 0.5 \mathrm{pMC}$ \\
\hline Microtus sp. & Friday Creek & AF32134 & Beta-154421 & $490 \pm 40 \mathrm{BP}$ \\
\hline Clethrionomys rutilus & Texas Gulch & AF32127 & Beta- 154420 & $910 \pm 40 \mathrm{BP}$ \\
\hline Microtus longicaudus & Friday Creek & AF32105 & Beta- 154418 & $1120 \pm 40 \mathrm{BP}$ \\
\hline Clethrionomys rutilus & Friday Creek & AF32153 & Beta-154422 & $3220 \pm 40 \mathrm{BP}$ \\
\hline Alces & Sandpiper & $\mathrm{JbVa}-2$ & Beta-164994 & $121.5 \pm 0.6 \mathrm{pMC}$ \\
\hline Alces & Whitehorse & YHB-01-17 & Beta- 162883 & $5720 \pm 50 \mathrm{BP}$ \\
\hline Ovis dalli & Granger & YHB-01-60 & Beta-165099 & $670 \pm 40 \mathrm{BP}$ \\
\hline Oreamnos americanus & Sandpiper & YHB-01-31 & Beta-164993 & $2510 \pm 40 \mathrm{BP}$ \\
\hline Cervus & Whitehorse & YHB-01-27 & Beta- 162358 & $1540 \pm 40 \mathrm{BP}$ \\
\hline Cervus & Ibex & YHB-01-30 & Beta-164992 & $2690 \pm 40 \mathrm{BP}$ \\
\hline Bison $b$. Dung & Friday Creek & YHB-01-56 & Beta-165096 & $2840 \pm 60 \mathrm{BP}$ \\
\hline Bison $b^{1}$ & Mt Granger & GRA-99-12 & Beta-135361 & $7510 \pm 90 \mathrm{BP}$ \\
\hline
\end{tabular}

${ }^{1}$ First reported in Stephenson et al. (2001).

Ice patch bison remains are of particular interest to wildlife managers following the 1986 successful reintroduction of wood bison to southwest Yukon. The four ice patch bison dates (Table 4) combined with those $(\mathrm{N}=24)$ from other Yukon sites (Stephenson et al., 2001: Table 1; Harington, 2003) support the widespread occurrence of the species in the Yukon through the Holocene to as late as 370 BP (Harington, 2003). The occurrence of bison remains in ice patches extends the species' summer habitat use to high elevations. The extant herd is known to use the uplands from June through August (M. Oakley, Yukon Department of Environment, unpubl. data), to aggregate in the immediate vicinity of ice patches and to wallow in ancient dung at the Thulsoo ice patch (Fig. 2). These findings point to the cosmopolitan nature of the species, with its ability to exist in upland as well as low-elevation meadow habitats in the north. Two bison dung samples from Friday Creek, dating $2840 \pm 60$ and $3500 \pm 60$ years $\mathrm{BP}$, yielded diet composition typical for the average bison diet (Reynolds et al., 1978): grasses (59.3\%), sedges $(29.1 \%)$, forbs $(4.2 \%)$, shrubs $(2.8 \%)$, lichens $(3.0 \%)$, and mosses $(0.9 \%)$. Comparing these samples to the composition of modern dung collected from the Yukon herd in 2000 and 2001, we found that forbs (2.4\%), lichen (4.3\%), and moss $(2.0 \%)$ are correspondingly represented, while shrubs (7.2\%), grasses (24.2\%) and sedges (60.1\%) were significantly different (Student's t-test $p<.01$ ). Continued monitoring of the modern bison diet will be important to evaluate the present-day habitat suitability for this once extirpated species and its long-term significance to other plant and animal resources.

Wapiti is poorly documented in the Yukon, so its presence at the Ibex ice patch (Fig. 2) at $2690 \pm 40$ years BP (Table 4) is important for reconstructing the past large mammal community. The only other reliably dated occurrence in the study area (from an antler found near Whitehorse) is more recent, dated at $1540 \pm 40$ years BP. Although wapiti was reintroduced into southern Yukon in the 1950s, it has not appreciably extended its range or expanded its present numbers of about 200. Environmental conditions that apparently favoured the animal in the past do not appear to occur in the present boreal forest (Florkiewicz, 1994). Present herds remain largely confined to areas of recent burn and grassy, south-facing slopes.

Mountain goat from the Sandpiper ice patch (dated at $2510 \pm 40$ years BP; Table 4) provides the only date on goat from the Yukon. Sandpiper is only slightly outside the present range of the species ( $30 \mathrm{~km}$ south across Kusawa Lake) (Fig. 2). The $3570 \pm 40$ years BP date on sheep from Sandpiper 3 (Table 4) indicates that these two species may have been distributed sympatrically in this coastal ecotone area for the last 2500 years.

A moose humerus from the Sandpiper ice patch dated modern (Table 4). Other dates $(\mathrm{N}=13)$ place moose in the Yukon from mid to late Holocene. For the study area, moose remains from Whitehorse have been dated at 5720 \pm 50 years BP, and those from Aishihik Lake, at $2900 \pm 130$ years BP (Workman, 1978). Moose have expanded in western North America since the LIA (Kelsall, 1972; Kelsall and Telfer, 1974; LeResche, 1974; LeResche et al., 1974; Coady, 1980; Yesner, 1989; Spalding, 1990; Kay, 1997), coincidentally with apparent decreases in woodland caribou populations (Seip and Cichowski, 1996; Spaulding, 2000; this study) as forage composition and habitat areas changed. These changes likely affected predator/prey dynamics as well (Bergerud and Elliot, 1998).

Eighteen non-artifactual caribou elements were dated from the ice patches: a scapula dated at $3650 \pm 50 \mathrm{BP}$, and 17 
mandibles sampled for contaminants dated between 6320 and 360 years BP (P. Roach, Contaminants Unit of Indian and Northern Affairs Canada, Whitehorse, unpubl. data).

\section{DNA Studies}

Mitochondrial and nuclear DNA were successfully extracted from well-preserved caribou dung pellets. Five of eight pellets examined to this point produced microsatellite sequences, raising the possibility of positively correlating the ancient dung-and therefore use of a specific ice patch-with genotyped Yukon caribou herds (Zittlau et al., 2000). Ice patch dung stratigraphy may eventually provide a record of ice patch use by specific caribou herds through much of the Holocene and identify changes in ranging patterns traceable to specific environmental and ecological conditions, such as moisture and temperature fluctuations, changes in floral composition, and predation. In addition, DNA extracted from dung should help clarify caribou systematics and help identify postglacial distant ancestry of specific populations.

Knowledge of past genotypes and habitat use has significant implications for present caribou management because it documents natural populations and ecological changes. In recent years, some small caribou herds in the Yukon and Alaska have declined towards extirpation (Farnell and Gardner, 2003), and the choice must be made to intervene and reverse declines or to allow population declines to run their course. More specifically, management of the Ibex and Aishihik herds, no longer present in much of southwest Yukon, depends upon whether the herds had time depth in the region or represent the most recent appearance of a series of herd genotypes.

\section{Caribou Diet}

Caribou dung from the Friday Creek ice patch provides dietary information for the past 4500 years (Table 2). For comparison, modern late summer samples from the same snow-covered ice patch and immediate tundra surface were also analyzed, along with dung from the Ibex herd's winter range. Little difference in average dietary composition is evident between the ice patch Holocene diets and the summer diet of the Ibex herd. Both diets are dominated by shrubs (36\% ice patch and $37 \%$ Ibex), with smaller proportions of lichens (26\% and 26\%, respectively) and graminoids (18\% and $24 \%$, respectively). Only forbs (2.7\% and $7.3 \%$, respectively) were significantly different (Student's t-test $p<0.009$ ). In contrast, the ice patch diet differed markedly from the modern winter diet, which is dominated by $86 \%$ lichens. Similar results are reported for other herds wintering on lichen-rich ranges (Russell and Martell, 1984). These analyses indicate that the ice patch dung was deposited during the summer, when caribou seek out ice patches, and that this behaviour has persisted for most of the Holocene.

\section{Parasite Studies}

Three Friday Creek dung samples spanning the last 4500 years, as well as bulk samples collected from the ice patch margins, were examined for parasites. A sample from near the top of the patch tested negative, one from mid-slope yielded a single nematode of unknown species, and a lower sample (corresponding to $4410-4200 \mathrm{BP}$ ) contained a Giardia cyst, likely the earliest record of this parasite. The small parasite loads indicated by these samples, and in particular the bulk dung samples, may be the result of taphonomic processes, such as the multiple freezethaw cycles, that the dung has endured. Techniques of molecular identification may yield further qualitative results, but quantitative results through the ice patch stratigraphy appear unlikely.

\section{SUMMARY}

This paper provides an overview of research undertaken by the Ice Patch Research Project, with preliminary results. Ice patches, defined by the presence of layers of caribou dung pellets exposed during the height of summer melt, occur in alpine settings of southwest Yukon between 1550 and $2075 \mathrm{~m}$ asl on north-facing slopes or in nivation hollows. Approximately 72 ice patches appear to contain significant accumulations of caribou dung. Of these, 65 have been ground-checked, and 35 yielded mummified animal remains, bone, and antler in addition to dung. Eighteen patches of this latter group have also yielded evidence of prehistoric hunting activity. There appears to be a strong correlation between the abundance of artifacts and recovered faunal remains, suggesting that faunal remains may be byproducts of human hunting activity.

Forty radiocarbon dates on dung and animal remains provide a record of net ice accumulation spanning the past 8000 years. Dates from three reference ice patch sites, Thandlät, Granger, and Friday Creek, indicate a midHolocene hiatus in ice accumulation between ca. 6730 and 4780 BP that likely reflects increased temperatures, decreased precipitation, or both. Changes in ice patch size over the past 60 years correlate over decadal intervals with the Whitehorse record of annual mean summer temperatures (expressed as MDD).

Pollen and plant macrofossils have been recovered from fecal pellets and from bulk samples of "dirty" and "clean" ice. Organic-rich ice samples and dung contain numerous taxa that reflect various taphonomic pathways. Clean ice samples are dominated by spruce and pine pollen. Pine became an element in the vegetation of southern Yukon after 1900 years ago. Analysis of Holocene and modern caribou dung will help to distinguish seasonal differences in diet and further document seasonal use of the ice patches. Development of a pollen diagram based on stratigraphically controlled and dated ice patch samples will complement records derived from lake and bog sedi- 
ment cores to further our understanding of southern Yukon vegetation history. The ice patch pollen records combined with other data sets will greatly aid our understanding of ice patch development and palaeoclimate.

Studies of the preserved dung and animal remains are beginning to provide insight into large mammal paleobiology and community development during the Holocene. The discovery of bison and elk remains is of particular interest to Yukon wildlife managers and, together with other ice patch data, could assist in developing future management strategies. Especially important in this regard is the extraction of caribou mitochondrial and nuclear DNA, as these data will enable wildlife managers to document past herd affiliation and range use. Parasitology of the dung indicates low parasite loads, although poor preservation cannot be ruled out.

\section{ACKNOWLEDGEMENTS}

Many individuals and organizations have contributed to the research and related activities reported here and in the companion paper (Hare et al., 2004, this volume). Principal funding support has been provided by the Yukon Government, Departments of Environment and Tourism and Culture, as well as the Yukon Community Development Fund. Financial support also came from the Government of Canada (Department of the Environment, Northern Ecosystem Initiative). Additional support has been provided by the Canadian Wildlife Service, the University of Alberta, University of Alaska Museum, the American Bald Eagle Foundation of Alaska, the Yukon Development Corporation, and Parks Canada (Kluane National Park). The Government of Canada (Department of Indian and Northern Affairs) was the principal sponsor of the 2000 and 2001 First Nations Science Camp.

First Nation partners in the project are the Champagne and Aishihik First Nations (CAFN), Carcross/Tagish First Nation (CTFN), the Kwanlin Dün First Nation (KDFN), the Kluane First Nation (KFN), Ta'an Kwachan First Nation, and Teslin Tlingit Council. Particular thanks are due to Lawrence Joe and to the late Sarah Gaunt (CAFN) for their unfailing support of the project, and to Dan Cresswell and Bev Sembsmoen (CTFN), Sharon Mankowski and Josh Smith (KDFN), and Gerald Dickson and Robyn Bradasch (KFN). First Nation members who assisted with field work include James Baker, Maryann Carroll, Lenny Charlie, Josh Darbyshire, Aaron Doris, Robert Fox, Cody Joe, Kristina Kane, Robert McLaren, Steven Reid, Claude Smarch, and Marlene Smith-Tutin. Special acknowledgement must be made of the many contributions of the late Tagish Johns, who will be greatly missed. Appreciation is extended as well to the Elders who have assisted, with particular thanks to Art Johns and Jimmy G. Smith for their enthusiasm and commitment. Pilot Delmar Washington, Capital Helicopters, must be thanked for his support and assistance on many levels.

The efforts of the following individuals have made significant contributions to the Ice Patch Research Project: Kirstin Benedek, who originally discovered the ice patch phenomenon; Gerry Kuzyk, School of Environmental Sciences, Lakeland College; Don Russell, Canadian Wildlife Service; the team of small mammal researchers from the University of Alaska: Amy Runck, Kalin Kellie, Pat Cotter and Gordon Jarrell; Allan Cooper and Beth Shapiro, Ancient Biomolecules Centre, Oxford University; John Storer and Valery Monahan, Yukon Department of Tourism and Culture; Loralee Laberge and John Meikle, Yukon Department of Environment; Chris Thomas, University of Alberta; Scott Smith, Agriculture Canada; Jim Gilpin, Yukon College; Michael Gerasimoff, Icefield Instruments; Paul Mattheus, Alaska Quaternary Centre; Mike Dehn, Feet on the Ground Communications; and William Miller, Environment Canada. Weather data for this study were provided by Environment Canada (Whitehorse).

\section{REFERENCES}

ANDERSEN, J.R., and NILSSEN, A.C. 1998. Do reindeer aggregate on snow patches to reduce harassment by parasitic flies or to thermoregulate? Rangifer 18(1):3-17.

BANFIELD, A.W.F. 1974. The mammals of Canada. Toronto: University of Toronto Press.

BARNES, I., MATHEUS, P., SHAPIRO, B., JENSEN, D., and COOPER, A. 2002. Dynamics of Pleistocene population extinctions in Beringian brown bears. Science 295:2267-2270.

BERGLUND, A.T., and ELLIOT, J.P. 1998. Wolf predation in a multiple-ungulate system in northern British Columbia. Canadian Journal of Zoology 76:1551-1569.

BOURGEOIS, J.C. 1990. Seasonal and annual variation of pollen content in the snow of a Canadian High Arctic ice cap. Boreas:313-322.

2000. Seasonal and interannual pollen variability in snow layers of arctic ice caps. Review of Paleobotany and Palynology 108:17-36.

BOWYER, V., and SCHWEGER, C.E. 2001. Ice patch as context: Reconstructing Holocene alpine environments in the southern Yukon. Paper presented at the 34th Annual Conference, Canadian Archaeological Association. Banff, Alberta.

CHAMPAGNE AND AISHIHIK FIRST NATIONS (CAFN). n.d. Interview files and transcripts. Unpubl. ms. Materials on file at Heritage Office, Champagne and Aishihik First Nations, Haines Junction, Yukon, Y0B 1L0, Canada.

COADY, J.W. 1980. History of moose in northern Alaska and adjacent regions. Canadian Field-Naturalist 94:61-68.

CRUIKSHANK, J., SIDNEY, A., SMITH, K., and NED, A. 1990. Life lived like a story. Vancouver: UBC Press.

CWYNAR, L.C. 1988. Late Quaternary vegetation history of Kettlehole Pond, southwestern Yukon. Canadian Journal Forest Research 18:1270-1279.

CWYNAR, L.C., and SPEAR, R.W. 1995. Paleovegetation and paleoclimatic changes in the Yukon at 6 ka B.P. Géographie physique et Quaternaire 49:29-35.

DENTON, G.J., and KARLÉN, W. 1973. Holocene climatic variations: Their pattern and possible causes. Quaternary Research 3:155-205.

DENTON, G.J., and STUIVER, M. 1967. Late Pleistocene glacial stratigraphy and geochronology, northeastern St. Elias Mountains, Yukon Territory, Canada. Geological Society of America, Bulletin 78:485-510. 
DOWNES, C.M., THEBERGE, J.B., and SMITH, S.M. 1986. The influence of insects on the distribution, microhabitat choice, and behavior of the Burwash caribou herd. Canadian Journal of Zoology 64:622-629.

ELEY, F.J., and FINDLAY, B.F. 1977. Agroclimatic capability of southern portions of the Yukon Territory and Mackenzie District, NWT. Project Report No. 33. Unpubl. ms. available at Environment Canada, Atmospheric Environment Service, 4905 Dufferin Street, Downsview, Ontario M3H 5T4. 97 p.

FARNELL, R., and GARDNER, C. 2003. Status of the Chisana caribou herd 2002. Report TR-03-01. Whitehorse: Yukon Fish and Wildlife Branch.

FLORKIEWICZ, R.F. 1994. Nutritional ecology of wapiti and carrying capacity of late winter and spring range in the Yukon. M.Sc. Thesis. University of Alberta, Edmonton. 72 p.

GAJEWSKI, K., GARNEAU, M., and BOURGEOIS, J.C. 1995. Paleoenvironments of Canadian High Arctic derived from pollen and plant macrofossils: Problems and potentials. Quarternary Science Reviews 14(6):609-629.

GLEN, J.W. 1955. The creep of polycrystalline ice. Proceedings of the Royal Society of London, Series A (228):519-538.

GREER, S. 1986. Kusawa Lake archaeology: Management, research and interpretation. Unpubl. Ms. Available at Government of Yukon, Department of Business, Tourism and Culture, Box 2703, Whitehorse, Yukon, Y1A 2 C6.

HAEBERLI, W., SCHOTTERER, U., WAGENBACH, D., HAEBERLI-SCHWITTER, H., and BORTENSCHLAGER, S. 1983. Accumulation characteristics on a cold, high-alpine firn saddle from a snow-pit study on Colle Gnifetti, Monte Rosa, Swiss Alps. Journal of Glaciology 29(102):260-271.

HARE, P.G., GREER, S., GOTTHARDT, R., FARNELL, R., BOWYER, V., SCHWEGER, C., and STRAND, D. 2004. Ethnographic and archaeological investigations of alpine ice patches in Southwest Yukon. Arctic 57(3):260-272.

HARINGTON, C.R., ed. 2003. Annotated bibliography of Quaternary vertebrates of northern North America - with radiocarbon dates. Toronto: University of Toronto Press.

HUGHES, M.K., and DIAZ, I.F. 1994. Was there a Medieval Warm Period, and if so, where and when? Climatic Change 26 (2-3):109-142.

ION, P.G., and KERSHAW, G.P. 1989. The selection of snow patches as relief habitat by woodland caribou: Rangifer tarandus caribou, Macmillan Pass, Selwyn/Mackenzie Mountains, NWT, Canada. Arctic and Alpine Research 21(2):203-211.

JANZON, L.-A. 1981. Airborne pollen grains under winter conditions. Grana 20:183-185.

KAY, C.E. 1997. Aboriginal overkill and the biogeography of moose in western North America. Alces 33:141-164.

KEENAN, T.J., and CWYNAR, L.C. 1992. Late Quarternary history of black spruce and grasslands in southwest Yukon Territory. Canadian Journal of Botany 70:1336-1345.

KELSALL, J.P. 1972. The northern limits of moose (Alces alces) in western Canada. Journal of Mammalogy 53(1):129-137.

KELSALL, J.P., and TELFER, E.S. 1974. Biogeography of moose with particular reference to western North America. Le Naturaliste Canadien 101:117-129.
KUZYK, G., RUSSELL, D.E., FARNELL, R.S., GOTTHARDT, R.M., HARE, P.G., and BLAKE, E. 1999. In pursuit of prehistoric caribou on Thandlät, southern Yukon. Arctic 52(2):214-219.

LACOURSE, T., and GAJEWSKI, K. 2000. Late Quaternary vegetation history of Sulphur Lake, southwest Yukon Territory, Canada. Arctic 53(1):27-35.

LERESCHE, R.E. 1974. Moose migrations in North America. Le Naturaliste Canadien 101:393-415.

LERESCHE, R.E., BISHOP, R.H., and COADY, J.W. 1974. Distribution and habitats of moose in Alaska. Le Naturaliste Canadien 101:143-178.

MACDONALD, G.M., and CWYNAR, L.C. 1985. A fossil pollen based reconstruction of the late Quaternary history of lodgepole pine (Pinus contorta ssp. latifolia) in the western interior of Canada. Canadian Journal of Forest Research 15:1039-1043. . 1991. Post-glacial population growth rates of Pinus contorta ssp. latifolia in western Canada. Journal of Ecology 79:417-429.

MILLER, M.M., and ANDERSON, J.H. 1974. Out of phase Holocene climatic trends in the maritime and continental sectors of the Alaska-Canada Boundary Range. In: Mahaney, W.C., ed. Quaternary environments: Proceedings of a symposium. Toronto: York University, Department of Geography. 33-58.

MOE, D. 1983. Palynology of sheep's faeces: Relationship between pollen content, diet and local pollen rain. Grana 22:105-113.

MOORE, P.D., WEBB, J.A., and COLLINSON, M.E. 1991. Pollen analysis. London: Blackwell Scientific.

PATERSON, W.S.B. 1981. The physics of glaciers, 2nd ed. Toronto: Pergamon.

RAMPTON, V. 1971. Late Quaternary vegetational and climatic history of the Snag-Klutlan Area, southwestern Yukon Territory, Canada. Geological Society of America Bulletin 82:959-978.

RASMUSSEN, P. 1993. Analysis of goat/sheep faeces from Egolzwil3, Switzerland: Evidence for branch and twig foddering of livestock in the Neolithic. Journal of Archaeological Science 20:479-502.

REYNOLDS, H.W., HANSSEN, R.M., and PEDEN, D.G. 1978. Diets of the Slave River lowlands bison herd, Northwest Territories, Canada. Journal of Wildlife Management 42(3): $581-590$.

RUSSELL, D., and MARTELL, A.M. 1984. Winter range ecology of caribou (Rangifer tarandus). In: Olson R., Hastings, R., and Geddes, F., eds. Northern ecology and resource management. Edmonton: University of Alberta Press. 117-144.

SEIP, D.R., and CICHOWSKI, D.B. 1996. Population ecology of caribou in British Columbia. Rangifer Special Issue 9:73-80.

SMITH, C.A.S., ROOTS, C.F., and MIEKLE, J.C., eds. 2003. Yukon Southern Lakes, Ruby Ranges and Stikine Highlands. In: Ecoregions of the Yukon Territory. Agriculture and Agrifoods Canada. Unpubl. ms. available at the Yukon Department of Environment, Box 2703, Whitehorse, Yukon, Y1A 2 C6.

SPALDING, D.J. 1990. The early history of moose (Alces alces): Distribution and relative abundance in British Columbia. Contributions to Natural Science No. 11. Victoria: Royal British Columbia Museum.

. 2000. The early history of woodland caribou (Rangifer tarandus caribou) in British Columbia. Wildlife Bulletin No. B100. Victoria: B.C. Environment. 
STEPHENSON, R.O., GERLACH, S.C., GUTHRIE, R.D., HARINGTON, C.R., MILLS, R.O., and HARE, P.G. 2001. Wood bison in late Holocene Alaska and adjacent Canada: Paleontological, archeological and historical records. In: Gerlach, S.C., and Murray, M.S., eds. Wildlife and people in northern North America. Essays in honor of R. Dale Guthrie. British Archaeological Reports International Series 2001:125-159.

STUART, G.S.L., HELMER, J.W., and HILLS, L.V. 1989. The Holocene paleoecology of Jenny Lake area, southwest Yukon, and its implications for prehistory. Arctic 42(4):347-353.

VAN DER KNAPP, W.O. 1989. Past vegetation and reindeer on Edgoya (Spitsbergen) between c. 7900 and c. 3800 B.P., studied by means of peat layers and reindeer faecal pellets. Journal of Biogeography (1989) 16:379-394.

WAHL, H.E., FRAZER, D.B., HARVEY, R.C., and MAXWELL, J.B. 1987. Climate of the Yukon. Climatological Studies No. 40. Ottawa: Environment Canada. 323 p.

WANG, X., and GUERTS, M. 1991a. Late Quaternary pollen records and vegetation history of the southwest Yukon Territory: A review. Géographie physique et Quaternaire 45(2):175-193. 1991b. Post-glacial vegetation history of the Ittlemit Lake Basin, southwest Yukon Territory. Arctic 44(1):23-30.

WASHBURN, A.L. 1979. Geocryology. London: Edward Arnold. WORKMAN, W.B. 1978. Prehistory of the Aishihik-Kluane Area, southwest Yukon Territory. National Museum of Man Mercury Series, Archaeological Survey of Canada Paper No. 74. Ottawa: National Museum of Man.

YESNER, D.R 1989. Moose hunters of the boreal forest? A reexamination of subsistence patterns in the western Subarctic. Arctic 42(2):97-108.

ZITTLAU, K., COFFIN, J., FARNELL, R., KUZYK, G., and STROBECK, C. 2000. Genetic relationships in three Yukon woodland caribou herds determined by DNA typing. Rangifer Special Issue 12:59-62.

ZUTTER, C. 1999. Congruence or concordance in archaeobotany: Assessing micro- and macro-botanical data sets from Icelandic middens. Journal of Archaeological Science 26(7):833-844. 